\title{
Challenges and Opportunities of MICE Tourism Development in Arsi Zone Oromia Regional State of Ethiopia
}

\author{
Mesfin Worku Tola* \\ Department of Tourism Management, College of Business and Economics, Arsi University \\ Kinfe Abreha Gebremedihen \\ Department of Tourism Management, College of Business and Economics, Arsi University
}

\begin{abstract}
MICE tourism is the highest revenue generator segment of tourism industry in many countries around the world as well in Ethiopia. Arsi Zone has good potential for MICE tourism development. But the area is not appropriately used the existing potentials. Thus, as to look into the problems and achieve the objective of the study used descriptive research design with mixed research approach. The data was collected through questionnaire, interview, focus group discussion, and field observation. So as to collect data and information the study used both primary and secondary sources. The collected data were coded, processed and analyzed with the help of SPSS. The findings of this study show that athletics sporting events, Irreecha Ritual practices, Epiphany \& Meskel events, Meetings of regional and zonal level and local Exhibitions were the major types of MICE tourism in the area. Also the finding shows MICE Tourism provides an opportunity for shared experience, expanding cultural perspective, building community pride, social cohesion, attracts tourists to the area, job creation and boosts local economy, and increase the interaction between locals and tourists. The finding also shows the challenges of MICE tourism development; that includes lack of attention to this segment of tourism, lack of infrastructure, crime, and inflated prices during the time of celebrating events. To promote MICE tourism development; encourage private sectors and sponsors participation in event tourism development activities, create awareness for the local community towards the importance of event tourism development in the area.
\end{abstract}

Keywords: Tourism, MICE Tourism, Challenges, Opportunities

Abbreviations/Acronyms

AIDS:-Acquired Immune Deficiency Syndrome

CEIR: - Center For Exhibition Industry Research

FGD; - Focus Group Discussion

MICE: - Meeting, Incentives, Conventions/Conferences, and Exhibitions

UN; - United Nations

UNWTO: - United Nations World Tourism Organization

US; - United States

WTO: - World Tourism Organization

DOI: $10.7176 / \mathrm{JTHS} / 51-03$

Publication date:October $31^{\text {st }} 2020$

\section{Introduction}

\subsection{Background of the study}

Though there are varied definitions for the word tourism, definition provided by WTO is internationally accepted. The term as defined by WTO: "it comprises the activities of persons travelling to and staying in places outside their usual environment for not more than one consecutive year for leisure, business and other purposes not related to the exercise of an activity remunerated from within the place visited." There are different kinds of tourism, to mention few; adventure tourism, business tourism, MICE Tourism (rarely used interchangeably with conference tourism), sustainable tourism, social tourism and ecotourism. MICE Tourism is very profitable segment of tourism. The term MICE (Meetings, Incentives, Conventions and Exhibitions) represents a sector of tourism which includes meetings, exhibitions, conference tourism, business events and activities. Travelers attending MICE activities have a purpose beyond leisure tourism, and are in fact business travelers. These business travelers are connected to different sectors of the tourism and hospitality industry through their MICE activities. Think of business travelers who travel to a city to attend an exhibition. They will need food, drinks, shopping, entertainment, transport, accommodation and more.

MICE tourism can contribute significantly to the development of a tourism destination. As Ethiopian market is a large source market for MICE tourism, it is a promising target market for MICE suppliers. Conference tourism and small scale meetings are the most promising segments. The most important requirements of MICE buyers are unique experiences, high quality services, sufficient capacity, flexibility, value for money and professionalism.

"Events are temporary occurrences ...They have a finite length, and for planned events this is usually fixed and publicized" (Getz 1997). Public or private, commercial or charitable, celebratory or commemorative-events 
bring people together to share an experience and produce a measurable outcome (Silvers, 2004).

Today the tourism industry in Ethiopia is among the economic pillars of countries Economy. Currently Ethiopian government gave due attention to tourism sector. Ethiopian tourism development challenged by different factors, to mention some weak promotion, lack of trained manpower, lack of finance, lack of infrastructure and poor management capacity are the major one. At this time Ministry of Culture and Tourism, the highest national tourism organization, highly encourage both foreign and local investors to develop tourism.

\section{2 statement of the problem}

MICE tourism (Meetings, Incentive travels, Conferences, and Exhibitions) has been described as a new segment of tourism industry; a new type of tourism arising out of the increase in number of conventions and exhibitions; the fastest growing segment and most lucrative sector of the travel and tourism industry (Goldblatt, J., 2005; Getz 2012, 2013).

Several studies have been conducted to reveal the importance of MICE destination attributes (Lee and Back, 2007) examined the role of MICE destination attributes on forming the overall destination image. The meetings, incentive travel, conventions, and exhibitions (MICE) industry has been recognized as a significant market segment over the past decades (Astroff \& Abbey, 2006). The industry consists of multi-sectors of hospitality service including lodging, food and beverage, catering, convention service, convention facility supply, transportation, tourism, retail, and entertainment (Astroff\& Abbey, 2006; Fenich, 2008).

MICE tourism is the main factor for economic growth alleviation of poverty and the up grading of social capital and service. The growth of an economic output can be attributed to high investment in MICE tourism. Empirical studies have shown that investment plays a very important role in the growth of both developed and the underdeveloped economies (Bradley, Hall and Harrison, 2002).

Currently the federal as well as the regional government of Ethiopia devoted much effort on identifying problems on MICE investment and correcting them, searching potential investment areas, conducting continues reforms in policy and proclamation to increase the participation of private investors. Arsi Zone has the potential to be favorable for MICE tourism investment. Investors, on the other hand faced problems in running their business and participation. Such as marketing problem, lack of accessible development of infrastructure, lack of advertising and promotion, lack of giving enough land size to investors, financial problem, policy related problems, problem related to license, technological related problems, problem of taxation and human resource problems.

Several factors have contributed to low level of private investment growth on MICE in Ethiopia specifically in Arsi Zone. Thus, the role of MICE destination attributes on forming touristic image has not been evaluated. Therefore, this study aims to fill this research gap by investigating Challenges and opportunities of MICE tourism in Arsi Zone.

\subsection{Objectives of the Study}

\subsubsection{General Objectives}

The general objective of this research is to assess the challenges and opportunities of MICE tourism development in Arsi Zone.

1.3.2 Specific Objectives

The study is aimed to:

1. To identify the types of MICE tourism activities existed and the best ones to develop in the future in Arsi Zone.

2. To describe the challenges of MICE tourism development in Arsi Zone.

3. To identify the available opportunities of MICE tourism development in Arsi Zone.

\subsection{Research Questions}

The research was try to answer the following questions

Which types of MICE events exist and what are the best ones to develop in the future in Arsi Zone?

What are the challenges of MICE tourism development Arsi Zone?

What are the opportunities of MICE tourism development in Arsi Zone?

\subsection{Significance of the study}

This study is significant in providing information about challenge and opportunity of MICE tourism development in Arsi Zone. It also provides information for policy makers about minimizing the problems of MICE tourism in this town and this research paper would serve as corner stone for those who want to study in this area. And it can give a fairly clear picture on the excited contribution and challenges of MICE tourism in Arsi Zone for new investors. For the researchers, it develops the knowledge that the researchers have towards the issue and gain different experience of undertaking the study. For other researchers who are engaged in searching the information related to MICE tourism can use this research paper as a source of information. 


\subsection{Definition of key terms}

Tourism; The activities of persons travelling to and staying in places outside their usual environment for not more than one consecutive year for leisure, business and other purposes not related to the exercise of an activity remunerated from within the place visited(WTO 2001).

MICE; the word abbreviated from Meetings, Incentives, Conventions/Conferences and Exhibition.

MICE tourism; is a term that encompasses four different components of the corporate meeting's, market-meetings, incentives, conventions and exhibitions-which are all separate activities.

Opportunities; a good position, chance, or prospect as for advancement or success.

Challenges; the obstacles or to demand as due or deserved.

\section{Concepts of MICE Tourism}

The term tourism is one of the most controversial concepts which have no distinct universally accepted definition. Therefore, different scholars define the word tourism in different ways at different times. (Brohman, 1996), defined tourism as the sum total of the operators mainly has an economic nature, which directly relates to the entry, stay and movement of foreigners inside and outside a certain country, city or region. The most widely used definition of tourism today is the one given and approved by the UNWTO in 2001. The development of recreation and enjoyment; resulted from the surplus production since the industrial revolution, bring the new sector known as the smokeless industry; tourism. Industrial revolution made things easier and easier; because it helps over production of goods and reduces the need of too much labor force.

\subsection{MICE Tourism Definition}

The term MICE (Meetings, Incentives, Conventions and Exhibitions) represents a sector of tourism which includes business events and activities. Travelers attending MICE activities have a purpose beyond leisure tourism, and are in fact business travelers. These business travelers are connected to different sectors of the tourism and hospitality industry through their MICE activities. Think of business travelers who travel to a city to attend an exhibition. They will need food, drinks, shopping, entertainment, transport, accommodation and more. MICE have emerged as a critical component of tourism industry. A meeting is "a conference, workshop, seminar, or other event designed to bring people together for the purpose of exchanging information" (Montgomery \&Strick, 1995).

The Meetings, Incentives, Conventions and Exhibitions (MICE) sector of tourism is rapidly growing around the world. Once referred to as CEMI by Fenich (2008), the convention, exposition and meetings industry is ever changing. Many benefits from MICE tourism can be recognized, including among others its contribution to: employment and income in a region, the generation of investment in tourism/recreation infrastructure, the support of the formation of relationships between firms, the upholding of national interest and international cooperation, the allowance for training and educational opportunities, the facilitation of the exchange of new ideas and technology, the establishment of valuable scientific, business, professional and social contacts, and the promotion of a country or region as a tourist destination for vacation travel (Dwyer \& Forsyth, 1997).

The convention industry tends to attract high-spending visitors and those who make repeat visits to a destination. Researchers have suggested that MICE travelers tend to stay longer at a destination and spend more than the average traveler (Bradley, Hall and Harrison, 2002). A trend that began to develop several years ago is that business travelers are mixing business with pleasure. Spouses and children are accompanying the business traveler domestically and internationally, and with the availability of resort activities this usually means the visitor will stay for one or two days' longer (Williams, M. and Bowdin, G.A.J., 2007).

There is limited agreement about a universally accepted definition for the MICE tourism industry. It is however, possible to categories four types of MICE events that is: meetings, incentives, conventions and exhibitions which are frequently linked to MICE tourism markets. In the context of MICE tourism destinations, the present research views MICE tourism industry as occupying one where individuals gather to exchange new information and products associated with the business or organization.

\subsection{Components of MICE Tourism}

The universe of MICE tourism is amazingly diverse, and any classification is bound to be incomplete. The different categories of planned MICE tourism can be found in virtually every culture and community. They can be linked by way of economic development and tourism policy, through cultural strategies or by professional even managers, yet they are often produced and managed in complete isolation from each other. A great exercise for students and researchers is to attempt an inventory of all these types of events an exercise that is bound to result in frustration owing to the large number of MICE activities. Recognizing the importance of categorizing events, (Getz 2012, 2013) provides a classification of tourism events discussed below. The detail explanation of MICE and the related ones are as follows; -

2.2.1 Meetings

In general, MICE events are events and activities that involve attendees who share a common interest and gather 
in a place. The place for the gathering needs to be a venue arranged beforehand. The venue will provide space and facilities necessary to satisfy the needs of those who attend the gathering. Montgomery and Strick (1995): Meetings bring people together in one place for the purposes of sharing information and discussing and solving problems. Meeting attendance can range from ten to thousands of people. During a meeting, there will usually be food and beverage served. Meeting times vary depending on the meeting type.

\subsubsection{Incentives}

Incentive travel is a management tool for rewarding and motivating sales representatives, dealers, distributors, production workers, support staff, and in some cases, customers. The company rewards sales representatives who reach sales targets by sending them on trips. Usually, the incentive trip will last three days, with hotel stays, tour packages and planned activities such as dinners, parties and games. Montgomery and Strick (1995):

\subsubsection{Conventions}

Similar to meetings, conventions are gatherings of people with common objectives, organized to exchange ideas, views and information of common interest to the group. An organization, usually an association, will organize a convention each year with a theme related to the organization's topic. Those interested in registering for the convention can pay the association a fee for all the sessions, discussions, food and beverage, dinners, and site visits. Montgomery and Strick (1995):

\subsubsection{Exhibitions}

Exhibitions are activities organized to show new products, services and information to people who have an interest in them, such as potential customers or buyers. The company showing their new products, the exhibitor, typically rents an area from the organizer and sets up a booth to meet with potential buyers. The buyers or the public need an invitation or a ticket to be allowed into the exhibition.

\subsubsection{Festival Events}

Festivals are one of the most common forms of cultural celebration, and while many are traditional, with long histories, the majorities have been created in recent decades. Many of the other major types of event, especially art and entertainment, are frequently found within or as the theme of festivals. Art festivals are universal, but with considerable diversity in form and types of art featured. While traditional festivals often retain religious or mystical roots, contemporary festivals are primarily secular. Different cultural festivals are held in Arsi Zone in different times, this is a good example of festival event and this is also can be source of income.

2.2.6 Sport events

The sport event apart from being a form of tourism has in past time been one of the oldest and most sustaining activities of the human race. Sport events is a fast growing segment of the entire events industry just like every other segment, and it entails both individual sports and multi-sport events. Sport events have a very viable potential of attracting tourist visitors and also generate media exposure and economic impacts to host nations or destinations. For this reason, most government event strategies and destination marketing programs have been earmarked towards it. Apart from benefiting the host government, destination or organization, it also benefits participants involved and gives entertainment and enjoyment to spectators (Allen et al, 2011). Different kinds of national, regional and zonal sport events are held in Arsi Zone in recent years. These sport events are a source of income for the local community by providing accommodations and different things.

\subsection{Opportunities and Benefits of MICE Tourism Development}

The opportunities of the MICE tourism for the local economy and community are great and manifest themselves. They are; improving the image, which spreading positive attitudes about a particular area as well as the whole country, and other opportunity is economic sphere; which is also event as the increase in tourist consumption and opening many job vacancies during the event, due to material sphere; which is the construction of facilities of infra and supra structure, as well as an opportunity to the socio/cultural sphere; that means increasing the level of interest of local people to participant in activities related to the event, reinforcing traditional values and customs at the destination, and there is a psychological sphere; that increasing local pride and community spirit.

The benefit of MICE Tourism includes; Economic benefits that increase the level of economic development by earning hard currency for the host population. Events are seen to increase job (employment) opportunities and to work as catalysts in stimulating infrastructure. We can boost the local business by extending the length of stay of MICE participants. MICE tourism are also considered as important means to liven up destinations during offpeak seasons and play a significant role in generating repeat visits to destinations.

The other benefit of MICE Tourism is Socio-cultural benefits of MICE tourism; MICE tourism benefits socioculturally on a host community by way of strengthening the regional values or traditions. Moreover, host- guest interaction is improved through joint participation in festivals and events, it can also create cultural share between the participants and the host community (Getz,(1997). The attractiveness of destinations to both tourists and the local people, raise publicity and media coverage of destinations, and enhance destination images. 


\subsection{Challenges of MICE Tourism Development}

There are some challenges of MICE tourism development. Such as; there are environmental issues involved in operating an event; the most obvious being the repercussion of transportation. This contributes to greenhouse toxic emission as well as other negative effects on natural resources. The problem can also be found in the volume of rubbish produced and the need for their disposal. The major areas of impact of events are energy, transport, waste management, waste reduction and resource recovery, including materials purchasing and procurement.

High usage of these elements creates undesirable effects to the ecosystem. For example, using transportation during an event produces an amount of toxic emission that will affect the ecosystem. As to overcome this problem, the event organizers should limit the number of vehicles used in an event. For example, providing shuttle busses help reduce the usage of smaller vehicles that may only carry little load.

Reducing environmental impact from transportation becomes one of the main problems in event management. Hence, it is important that event stakeholder's practices environmental protection during organizing an event. Pollution; is one of the major problems of tourist industry all over the world (UNWTO, 2008).Like Water pollution; Water surfaces situated in and nearby event areas are usually exposed to significant environmental threats and pollution, which may be caused by the maintenance of additional facilities supporting events. Air pollution; from event tourist transportation that treat on the global level, especially from carbon dioxide emissions. Sewage; it is a factor that provides basic life conditions for both local residents and the natural environment.

\subsection{Conceptual Framework of the Study}

Figure1: Conceptual Framework

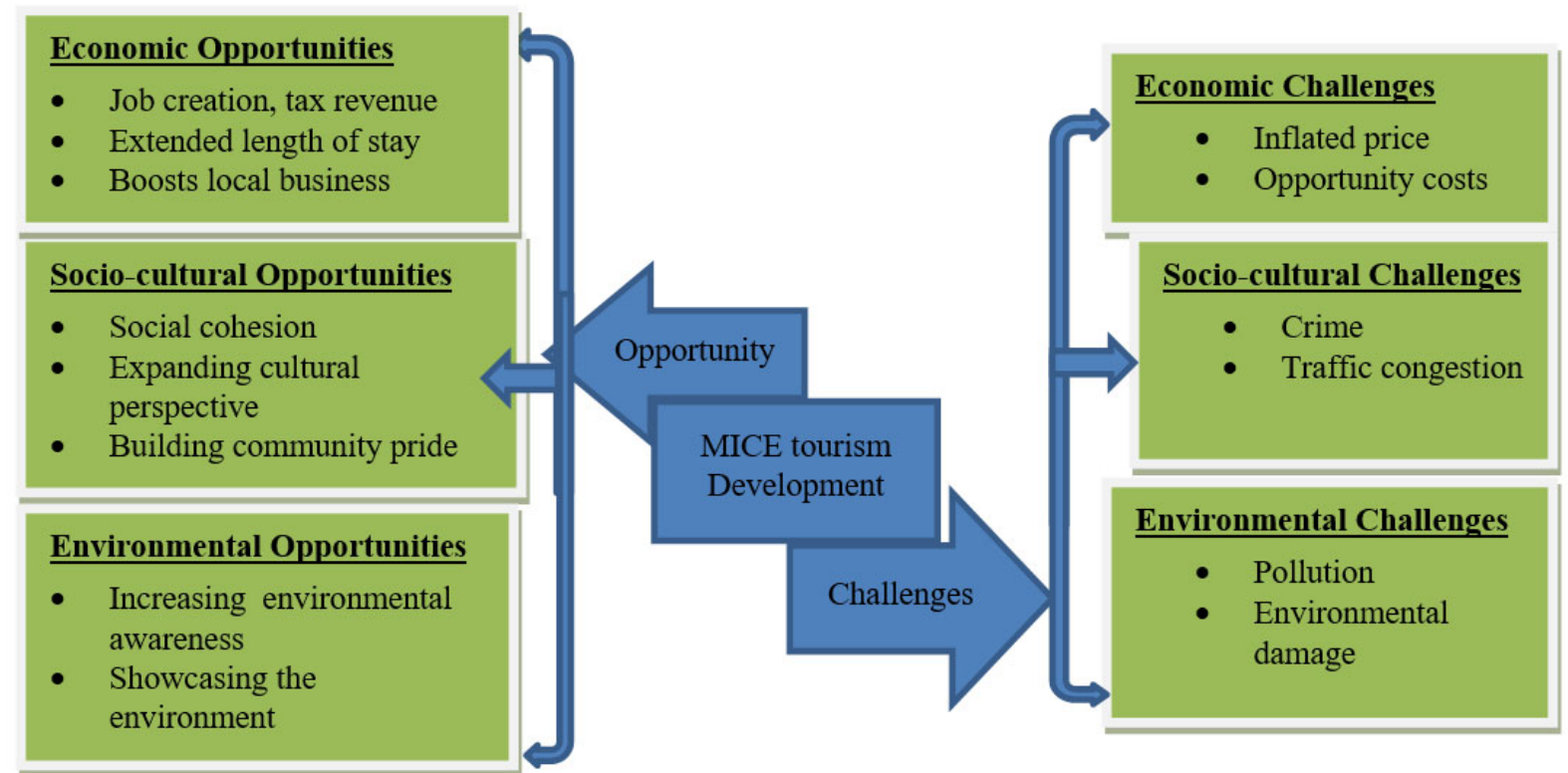




\subsection{Description of the study area}

Figure 2: Map of Study areas

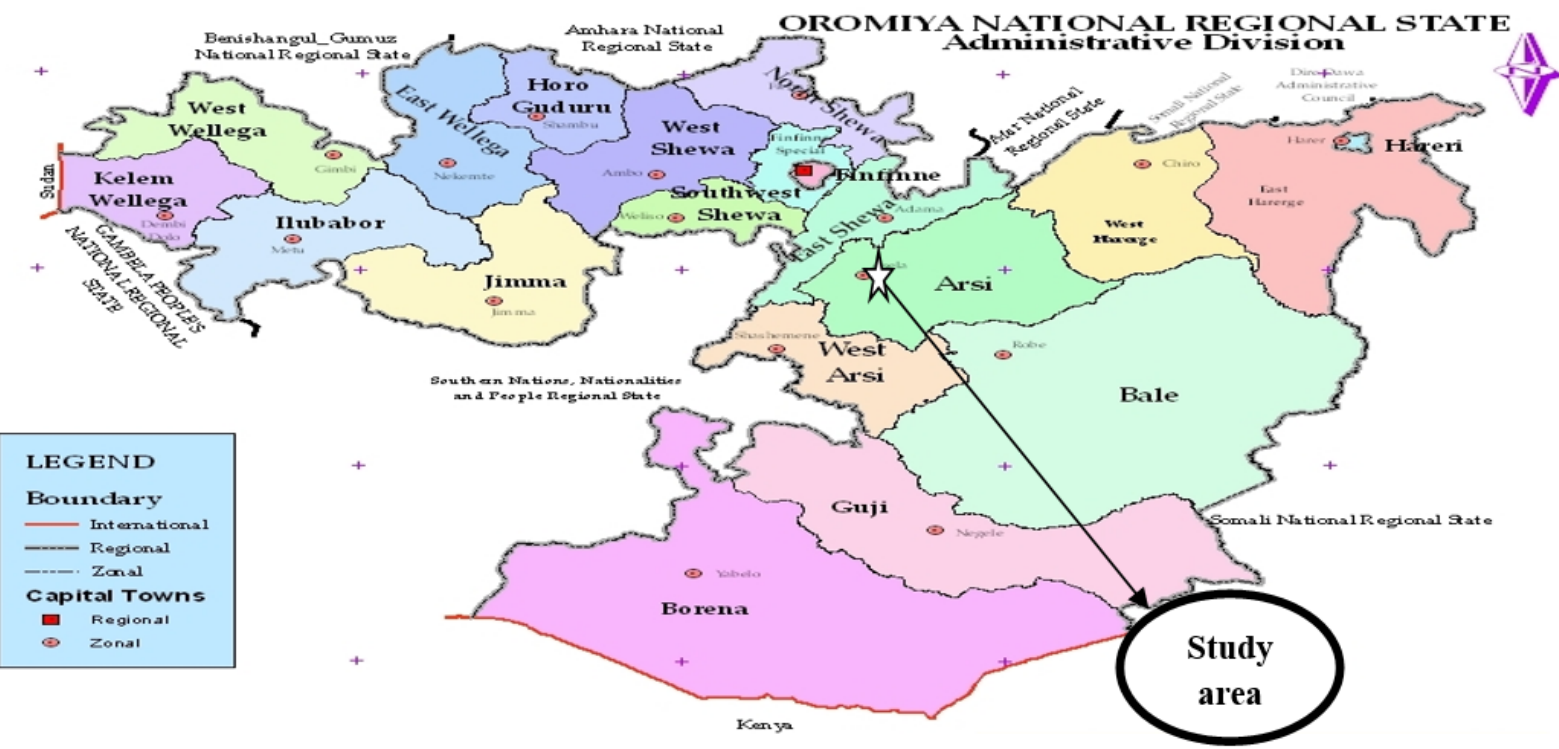

Source: Oromia Culture and Tourism Bureau Official web page, 2020

Arsi Zone is located in Oromia region central Ethiopia. This zone has a latitude and longitude of Latitude: $7^{\circ} 44^{\prime} 59.99^{\prime \prime} \mathrm{N}$ Longitude: $39^{\circ} 29^{\prime} 59.99^{\prime \prime}$ E. Asella is the capital of Arsi zone of Oromia regional state. It retains some administrative functions as the seat of the present Arsi zone. According to the data obtained from the structural plan of Assela town, Arsi Zone known for its mountain like mountain Chilalo (4139 meters above sea level) and Mount kaka (3400 meters above sea level). Arsi Zone located in Oromia Regional State about 175 kilometers far from Addis Ababa, the capital of Ethiopia, and $75 \mathrm{~km}$ far from Adama, making the capital the center of reference.

\subsection{Research Design and approach}

The research was designed to be Explanatory which is the most commonly used research design for a problem which was not well researched before in- depth and can also be used to investigate issues that request urgencies (Creswell, 2014).

The research employed mixed approach (qualitative \& quantitative), for conducting more scientific work and to cover the weakness of one approach by the other. Purposive sampling technique was used to select samples from officials working in the Zone and Woreda Culture and Tourism offices, Hotel Staffs, destination managers, NGOs and etc.

The qualitative data was subject to narrations. Those data, which attained from focused group discussion, observation and interviews, was organized, reduced and analyzed based on systematic grouping and content analysis to describe phenomena into their respective thematic areas.

The quantitative data was analyzed and interpreted using SPSS. The qualitative and quantitative data were first analyzed independently and then triangulated to make strong the finding of the study. Then, serious interpretation was followed to come up with representative finding which contribute more for the development of MICE tourism in the study areas.

\subsection{Target population of Study}

$>$ Tourism experts in culture and tourism offices from woreda's and zone

$>$ Managers in culture and tourism offices and administrators at woreda and zone

$>$ Local communities,

Hotel owners and staffs of two star hotels (Hotels that used by tourist)

$>$ Both international and domestic Tourists

$>$ Tourism Professionals from selected tour operators and Travel agencies

\subsection{Data Collection Instruments and Data Source}

The study used different types of data gathering instruments to collect data from both primary and secondary data sources. The techniques that were employed to gather data were:

$>$ Questionnaire,

$>$ Focused group discussion, 
Interview and Observation through developed checklist

Purposive and accidental sampling technique were used to select participants for FGDs and Interview. Participants for FGDs and interview were selected based on the distribution of the main tourism attractions, experiences, skills and knowledge on the theme of the research. The semi-structured interview was employed to get in-depth information from tourism experts and managers in culture and tourism offices and administrators at woreda and zonal level, visitors, staffs of accommodations and tourist site managers. Both the open-ended and closed ended items were included in the structured questionnaire. Random sampling technique was used for questionnaire. Also Published and unpublished materials, books, and journal articles were used as major secondary sources of data.

\subsection{Sampling Technique and sample size}

Woredas (districts) where MICE tourism potentials are relatively concentrated were the primary and secondary sampling units respectively. The selected 3 top woredas that have good potentials for MICE Tourism development includes; Assela Town (Tiyo woreda), Bokoji Town (Lemu Bilbilo Wored) and Dera town (Dodota woreda). These woreda's were selected based on their potencial. The sample size was determined using the following formula. It were allocated disproportionally to the sample woredas or kebeles based on the availability of tourism activities and/ or tourism resource. (Yemane, 1967 formula).

$\mathrm{n}=\frac{\mathrm{N}}{1+\mathrm{N}(\mathrm{e})^{2}}$

Where $\mathrm{n}$ is for required sample size, $\mathrm{N}$ is population size, the formula uses a $95 \%$ a confidence level and e is level of precision or sampling error which is $.05(+/-5 \%)(\mathrm{e}=.05)$ are assumed. According to the data taken from Arsi Zone Culture and Tourism office, the highest MICE participant tourist were registered in the year 2018 and figured nearly 1000 including both domestic and international participants. The researchers used this figure to determine the sample size.

So we get $\mathrm{n}=\frac{1000}{1+1000(.05)^{2}}=285.7$

So randomly samples of 286 people were communicated through questionnaire. Besides, 29 interviewees from ( 2 zone administrators, 3 kebele chairpersons, 3 tourism experts from the target woredas, 3 sample woreda administrators, 3 zone experts and 1 head from zone culture\& tourism office, 5 hotel managers (from two star hotels), 5 local communities from elders, 2 Tourism Professionals ( 1 from travel agency and 1 tour operators), 2 Tourist site managers were communicated.

One Focus Group Discussion was communicated with 5 stakeholders' discussants. Finally, 286 Questionnaires for sample respondents, 29 interviewees, 5 FGD participants were assessed from the study areas and totally 320 individuals were conducted for this research.

\subsection{Method of Data Analysis and Interpretation}

The processes of data analysis were carried out quantitatively and qualitatively. Initially, information that was gained through Afan Oromo language was translated and interpreted into English. The pre-coded quantifiable data were analyzed using Statistical Package for Social Science (SPSS) software. The qualitative data (information from interviews, FGD, open-ended questions, and others were discussed using the qualitative description.

\section{Results and Discussions}

\subsection{Major types of MICE Tourism Activities in Arsi Zone}

Table 4.1: Major types of MICE Tourism activities

\begin{tabular}{|l|l|l|l|l|}
\hline Variable & Options & Responses & Percent \\
\cline { 3 - 5 } & & & Percent \\
Caf \\
Cases
\end{tabular}

Source: Researchers own survey, 2019.

As the above table 4.1, shows that most of them chosen more than one, the maximum number of respondents (73.4\% number of respondents accounting about $21.9 \%$ share) said that sporting events, especially sports related to athletics, were the uppermost tourism events exist. Irreecha ritual practices and Epiphany \& Meskel festivals 
are the next uppermost tourism events counting $71.7 \%$ with $21.4 \%$ share and $66.4 \%$ with $19.8 \%$ share respectively. Regional and zonal meetings are other major MICE tourism activities which were chosen by $52.4 \%$ respondents with a share of $15.8 \%$ respondents. Mainly different kinds of regional and zonal meeting was frequently held in Asella town, the turning point is that the opening of new government owned meeting hall that equipped with latest meeting facilities. This meeting hall allows to held different kinds of meetings, like seminars, workshops, panel discussion and forum. Proportionated number of respondent indicated that local exhibitions or consumer shows (38.5\% of respondent with $11.5 \%$ share) and conferences or convention (32.2\% of respondent with $9.6 \%$ share) were among tourism events practiced in the research area.

Based on this the researchers concluded that sporting events, Irreecha ritual practices, Epiphany \& Meskel festival, regional and zonal meetings, local exhibitions (consumer shows) and conferences were the major types of MICE tourism activities exercised in the research area. Arsi zone especially Asella town is the best place for athletic related sporting events. Arsi Zone is known for world class athletes like Haile Gebresilassie, Derartu Tulu, Tirunesh Dibaba and her family, Kenenisa Bekele and so on. These popular athletes make an area to be known as best destination for sporting events. In addition to this Arsi Zone has high altitude advantage that makes among best place in the world to train and held athletics events. The data collected through interview and FGD support this conclusion.

\subsection{Opportunities of MICE Tourism Development}

The opportunities of MICE tourism development for the local economy and community are analyzed using 5 point likert scale to measure socio- cultural, environmental, economic, political, entertainment benefit of MICE tourism. The typical Likert scale is used to rate respondents' degree to which they agree or disagree with a statement. The summarized results of each variable are presented below.

4.2.1 Socio-cultural benefit of MICE tourism

Socio- cultural benefit of MICE tourism development were measured to what level the respondents strongly agree or disagree with shared experience, building community pride and expanding cultural perspectives. As per respondents' feedback through Likert scale almost all respondents ( $95 \%$ of total respondents) were agreed with shared experience and building community pride, that MICE tourism brought for local community. And $86.7 \%$ of respondents were giving expanding cultural perspectives. This implies that the majority of respondents, above $90 \%$, perceive that MICE tourism development provides an opportunity to learn about and experience their and new cultures, obtain new skills and knowledge, and reflect on one's own cultural circumstances. The researchers also concluded that the community's pride can improved through MICE tourism. Events bring people together to share an experience and produce a measurable outcome (Silvers, 2004).

4.2.2 Economic benefit of MICE tourism development

Economic benefits measured from length of stay of tourist, tax revenue, job creation and investment point of view. Accordingly $90 \%$ of them agreed with extended length of stay, $70 \%$ of them agreed increase tax revenue, $90 \%$ of them were agreed job creation and $75 \%$ of respondent agreed attract investment. As majority responded MICE tourism is significantly contribute to improve the local economy. For example a single music consort can brought surplus income for organizers in addition to entertainment. National and international MICE events can create a number of temporary and permanent employment opportunities. MICE tourist and partakers who spend their money on services and goods during their stay in the destination give a big improvement to the local economy.

4.2.3 Environmental benefits of MICE tourism

Environmental benefit measured with environmental awareness and models for the best practice. Reflected that $76.7 \%$ of respondents chosen the increased environmental awareness variable, while $66.7 \%$ chosen for promote environmental practices. MICE Tourism also promotes environmental conservation if it properly managed. Poorly managed tourism events allow environmental pollution; for example a tourist availed to participate in athletics event irresponsibly might threw away used plastic water bottle alongside of the road. But if tourist and local are responsible enough it can play great role in raising environmental awareness and best practices.

\subsection{Challenges of MICE Tourism Development}

The challenges of MICE tourism development in economic, logistics, socio-cultural, environmental and other factors are presented with the following table. 
Table 4.2: Challenges of MICE Tourism Development

\begin{tabular}{|c|c|c|c|c|}
\hline \multirow[t]{2}{*}{ Variable } & \multirow[t]{2}{*}{ Options } & \multicolumn{2}{|c|}{ Responses } & \multirow{2}{*}{$\begin{array}{l}\text { Percent of } \\
\text { Cases }\end{array}$} \\
\hline & & $\mathrm{N}$ & Percent & \\
\hline \multirow{5}{*}{$\begin{array}{l}\text { Logistics/facility } \\
\text { challenges }\end{array}$} & Less availability of performance place & 250 & 27.1 & $87.4 \%$ \\
\hline & Open space for concert & 237 & 25.6 & $82.9 \%$ \\
\hline & Conference hall & 220 & 23.8 & $76.9 \%$ \\
\hline & Hotel rooms & 217 & 23.5 & $75.9 \%$ \\
\hline & Total & 924 & 100 & $323.1 \%$ \\
\hline \multirow{4}{*}{$\begin{array}{l}\text { Economic } \\
\text { challenge }\end{array}$} & Lack of finance & 267 & 35.3 & $93.4 \%$ \\
\hline & Limited infrastructural development & 250 & 33 & $87.4 \%$ \\
\hline & Inflated price & 240 & 31.7 & $83.9 \%$ \\
\hline & Total & 757 & 100 & $264.7 \%$ \\
\hline \multirow{5}{*}{$\begin{array}{l}\text { Socio-cultural } \\
\text { challenges }\end{array}$} & Loss of authenticity & 150 & 32.1 & $52.4 \%$ \\
\hline & Manipulation of community image & 92 & 19.7 & $32.2 \%$ \\
\hline & Social dislocation & 145 & 31.1 & $50.7 \%$ \\
\hline & Community alienation & 80 & 17.1 & $27.9 \%$ \\
\hline & Total & 467 & 100 & $163.2 \%$ \\
\hline \multirow{4}{*}{$\begin{array}{l}\text { Environmental } \\
\text { challenges }\end{array}$} & Destruction of heritage & 172 & 28.3 & $60.1 \%$ \\
\hline & Pollution & 193 & 31.7 & $67.5 \%$ \\
\hline & Noise disturbance & 243 & 40 & $85 \%$ \\
\hline & Total & 608 & 100 & $212.6 \%$ \\
\hline \multirow{5}{*}{$\begin{array}{l}\text { Management or } \\
\text { administrative } \\
\text { challenges }\end{array}$} & Risk of event failure/event cancelation & 203 & 27.5 & $71 \%$ \\
\hline & Lack of accountability & 140 & 19 & $49 \%$ \\
\hline & Manipulation of funds & 203 & 27.5 & $71 \%$ \\
\hline & lack of peace and security & 192 & 26 & $67.1 \%$ \\
\hline & Total & 738 & 100 & 258.1 \\
\hline \multirow[t]{3}{*}{ Hazards/treats } & Crime & 147 & 36.1 & $51.4 \%$ \\
\hline & Traffic congestion & 260 & 63.9 & $91 \%$ \\
\hline & Total & 407 & 100 & $142.4 \%$ \\
\hline
\end{tabular}

Source: Researchers own survey, 2019.

According to the above table the majority of respondents (above 75\%) indicated that the research area lacks logistics or facilities to organize MICE related events. The major logistics challenges indicate were less availability of performance place for outdoor events, no space for concert, lack of sufficient and latest conference hall and hotel rooms. This implies that stakeholders concern is very important to solve the challenges and make the place best place to organize MICE related events. Logistics or facilities are the basic requirement in the planning process of MICE events; qualities of tourist facility services are elements constituting a competitive advantage of one destination over another (Sylla M. et al, 2015).

The upper most economic challenges to develop MIICE tourism was lack of finance ( $93.4 \%$ of cases). This includes shortage of loan, lack of budget and fewer interests of sponsors. To encourage any kinds of events finance is the backbone; so loan providers, funders and sponsors need to promote. Also Limited infrastructural development $(87.4 \%)$ and inflated price $(83.9 \%)$ were other major economic challenges. Inflated price was seasonal, at the time MICE events were held create shortage on some goods and services.

As far as Socio-cultural challenges was concerned it is not a serious challenge for the area. The variables used to measure socio cultural challenges (loss of authenticity, manipulation of community image, Social dislocation, and Community alienation) figured below $50 \%$. These indicate that MICE related events were at introduction stage. From this the researchers concluded that events at introduction stage brought less sociocultural challenges and host guest interaction is good.

The above 4.2 table also indicated that the major environmental factors that affect MICE tourism development was noise (sound) disturbance (85\%). This was when outdoor events like concerts and sporting events held on public area. Relatively proportionated number of respondent chosen Destruction of heritage $(60.1 \%)$ and pollution (67.5\%). These pollutions include water, soil and air as a result of executing events. The researchers concluded that the variables like noise disturbance, destruction of heritage and Pollution were only a challenge when outdoor events were poorly managed.

Finally, according to the above table management or administrative challenge that hinders MICE tourism events in Arsi Zone were risk of event failure or cancelation (71\%), manipulation of funds (71\%) and lack of peace and security (67.1\%). In addition to this the respondent expressed the reason of hazards and treats associated with MICE tourism development from the total respondents were taken $91 \%$ said traffic congestion. Traffic congestion resulted from poor road infrastructure and parking; especially while organizing big national athletic 
events. So concerned stake holders need to solve this problem. Crime $(51.4 \%)$ was also treats to tourism events. The local thieves make a crime against tourists and event participants.

According to the data collected through interview and focus group discussion most of them said that MICE tourism brought an opportunity for cultural promotion, socio-economic improvement. Moreover, most respondents agreed that MICE tourism; provided an opportunity to have fun with family and friends, provided a chance to meet new people, increase entertainment opportunities for locals, promote culture, increases interaction between locals and tourists, increase media coverage of the area, attracts future business and showcased the area in a positive light.

It was also found during personal observation that responses on community benefits and perceptions in relation MICE tourism event, speculations can be drawn that:

$>$ Occasionally lack of peace and security

$>$ Some respondents do not know who in their communities benefited from this event.

$>$ Even though they highlighted that certain members of the community benefited, it is not clear how they go about doing so and there is no evidence in their communities which reflect direct or indirect community benefits from or as a result of this event.

$>$ Rarely respondents perceived that too much money spent on the MICE tourism could have been spent on other activities.

$>$ Some respondents were not aware of how the event is organized or managed; who are involved and the status of their involvement; and how much money is involved and the source of money involved in the event.

\section{Conclusions and Recommendation}

\subsection{Conclusion}

The study mainly focused to assess the challenges and opportunities of MICE tourism development in Arsi Zone. The results of this study indicated the types of MICE tourism events, and there opportunities and challenges. Sporting events especially athletics, Irreecha ritual practices, Epiphany \& Meskel festival, regional and zonal meetings, local exhibitions (consumer shows) and conferences were the major types of MICE tourism activities exercised in the research area. Arsi Zone is known for world class athletes like Haile Gebresilassie, Derartu Tulu, Tirunesh Dibaba and her family, Kenenisa Bekele and so on. These popular athletes and high altitude advantage make an area to be known as best destination in the world for athletics sporting events. MICE tourism can effectively be a crucial resource to attract different segments of visitors, according to the type and uniqueness of the event. These different types of tourism events provide revenues, resulting from those attending it and also offer an opportunity for leisure, social interaction and entertainment for the community and visitors. The opportunities of the MICE tourism for the local community includes improving the destination image through spreading positive attitudes about a particular area, to share experience, building community pride and provides an opportunity to learn about and experience their and new cultures, and obtain new skills and knowledge. The major economic benefits are employment creation, tax revenue, investment and through events tourist length of stay can be elongated. MICE events have the potential of creating more positive economic, social and cultural benefits provided it is organized in a very professional and ethical manner. To the visitor, the event is an opportunity for a leisure, social, or cultural experience outside the normal range of choices or beyond everyday experience. The major challenges of MICE tourism development in the research are were logistics/facility challenges like Less availability of performance place, hotel rooms, conference hall and open space for concert. Lacks of finance, limited infrastructural development and inflated price were the major economic challenge. In addition to this noise pollution, risk of event failure/event cancelation and traffic congestion were challenges to MICE tourism development.

\subsection{Recommendations}

$\checkmark$ Culture and tourism office of Arsi Zone, and Arsi University should work on creating awareness for the local community and other stakeholders towards the importance of MICE segment of tourism. Through creating awareness more sponsors can be interested in financing events.

$\checkmark \quad$ The first and most point that the researchers recommends is special attention should be given for peace and security of the area, because MICE events such as conferences, exhibitions and sporting's needs special security, safety and stability to host. Lack of peace and security leads to cancelation of events.

$\checkmark$ Encouraging local communities to participate in the events hosted in the area and there should be a means where residents are involved in the events from their own cultural background; this helps developing sense of belongingness. By way of introducing new ideas event organizers can expand the cultural horizon.

$\checkmark$ Especial attention should be given to encourage the larger cooperation's, sponsors/promoters, investors, private sectors, and the Asella town municipality to promote and invest in the development of the MICE tourism sector. If more finance is made available for the hosting of events, especially bigger events like 
athletics sport event, more tourists both local and internationally will be attracted to the town and the positive impacts will be great.

$\checkmark$ Developing and promoting a high-quality, sustainable, and inclusive program of public events to raise the profiles of the area as a MICE tourist destination.

\section{References}

Astroff \& Abbey, (2006). China's Inbound Tourist Revenue and Beijing Olympic Games China \& World Economy / $110-126$, Vol. 16, No. 4

Allen, J., O`Toole, W., Harris, R. \& McDonnell, I. (2011). Festival \& Special Event Management. Australia: John Wiley \& Sons.

Arsi Zone Culture and Tourism office Annual Report, 2018, unpublished.

Bradley, Hall and Harrison (2002). ,the Economic and Social Effects Analysis of MICE Tourism, International Journal of MICE

Brohman, J. (1996). New directions for tourism in the Third World.Annals of Tourism Research 23(1), 48-70

Creswell, J. W. (2014). Research Design: Qualitative, Quantitative and Mixed Methods Approaches, 4th ed., Thousand Oaks, CA: Sage

Dwyer \& Forsyth, (1997). Research methods in psychology (second Addition), Harlow, UK: Pearson Education Limited.

Fenich G., (2008). Meetings, Expositions, Events \& Conventions, 2nd Edition, East Carolina University, East Carolina University

Getz, D. (1997) Event management and event tourism (1st ed.), Cognizant Communications Corporation, NY

Getz D. (2012, 2013) Event tourism: Concepts, international case studies, and research Cognizant, New York

Goldblatt, J. (2005). Special Events: event leadership for a new world (4 Ed.). New Jersey: John Wiley and Sons.

Lee and Back. (2007).Hospitality internship placements: Analysis for United Kingdom and India. Journal of Services Research, 10(1), 85-99.

Montgomery and Strick (1995):Service personalization and loyalty. Journal of Services Marketing, 20(6), 391403.

Oromia Culture and Tourism Bureau Official web page, 2020

Silvers, J. (2004).Professional event coordination. Hoboken, NJ: Wiley

Sylla M. et al, (2015) Opportunities and Limitations for Mice Tourism Development In Łódź1, [online] Available https://www.scribd.com/document/402511412/tour-2015-0011, (September 20, 2020)

UNWTO Tourism Highlights, 2008 Edition

Williams, M. and Bowdin, G.A.J. (2007). Festival evaluation: An exploration of seven UK art festivals, Managing Leisure, 12(2/3), pp. 187-203.

WTO (2001), Tourism Highlight and Glossary of Tourism Terms. Spain, Madrid

Yemane T. (1967), Statistics; An Introductory Analysis. 2nd Edition., New York: Harper \& Row publisher 